\title{
Agricultural organizations as participants in professional and public accreditation of staff training quality in agricultural economy
}

\author{
F.T. Nezhmetdinova*, G. R. Fassakhova, N. Kh. Sharypova, and L. M. Faizrakhmanov \\ Kazan State Agrarian University, 420015 Kazan, Russia
}

\begin{abstract}
Modern changes in agricultural market raise the issue of staffing quality. However, there is a real gap between the needs of specific agricultural producers and those workers who come to this sphere after graduating from agricultural universities. There is a number of ways and forms to decrease this gap. One of these tools is an independent external assessment of the quality of learning outcomes in the form of professional and public accreditation, conducted by employers. At the same time, it has not yet become an effective instrument in Russian, but there are some legislative grounds for it. The paper presents the analysis of successful international experience of professional and public assessment of agricultural educational programs, including the universities of North America. In the context of the globalization of agriculture, the implementation of new technologies and food security provision, the introduction of the best practices of public and professional accreditation into the Russian system of training professional agrarian personnel is of particular importance.
\end{abstract}

\section{Introduction}

In modern conditions of the development of agricultural economy, there is the increased need for staffing, which meets the needs of agricultural market [1]. According to the surveys of employers in the Russian Federation, there is still a significant gap between personnel training and those professional competencies that are needed in labor market [2].

Today, digital technologies, robotization, artificial intelligence, genetic engineering are being introduced and used in agriculture. That is, everything that we associate with Industry 4.0 and digital economy. At the same time, the main educational programs that are implemented in Russian agricultural universities are slowly changing their content and so far rarely open new areas of training.

First of all, this is connected with the existing education system in Russia, based on federal state educational standards, the content of which does not change and its implementation in undergraduate programs takes 4 years. In modern conditions, knowledge during this time manages to become outdated by two times. As a result, a graduate of an agricultural university is not always able to start work immediately, since his competencies may not be enough.

At the same time, there is a problem when agricultural organizations, as the main employer in agricultural sector, are not active to participate in the development of professional standards and educational activities of an agricultural university. They are reluctant to provide their enterprises for practical training and rarely form a target order for training personnel for themselves [2]. It is possible to solve this acute problem to some extent using the procedure of professional and public accreditation, which is included in the current Russian legislation on education [3, 4].

However, it is often formal. Therefore, it is necessary to study the successful experience of professional accreditation of educational programs that exist in world practice.

Nowadays foreign countries develop a stable practice of using the mechanism of professional and public accreditation of an educational program or a cluster of educational programs [5-7]. In North America and Western Europe, there are many widespread models of public and professional assessment of the quality of educational programs by professional communities of engineers, lawyers and physicians [8].

\section{Materials and methods}

The methodological basis of the research was formed by the basic principles of scientific knowledge, namely the objectivity and complexity of scientific analysis. The research tasks caused the need to apply the following methods: historical retrospective, interdisciplinary and integrated approaches, systematization, retrospective and problem-chronological, comparative analysis and integrated approach to sources on research subject. 
The purpose of the research is to identify the main approaches to the independent assessment of the quality of training for the agricultural sector based on the analysis of the best practices of professional and public accreditation of agricultural programs and possible adaptation for the Russian labor market in agricultural sector.

\section{Results and discussion}

The development of public and professional accreditation has long history. Let us consider, using specific examples, the organization of the procedure for professional public accreditation of educational programs of agricultural sector in a number of countries of North America: the USA and Canada.

In Canada, in addition to quality assurance processes of institutional environment of an educational institution, some academic programs in professional fields are subject to accreditation by professional bodies at the provincial, Canadian or international levels (for example, in nursing, architecture and engineering). Professional organizations develop assessment programs to ensure that the content of university programs, teaching resources and research results are qualitative and meet expectations and competencies to support future professionals in their field of expertise. Some programs are also accredited on a voluntary basis (business).

There are also organizations responsible for licensing individual practitioners after graduating from professional programs at Canadian universities. Thus, for example, in the field of agriculture, Agricultural Institute of Canada (AIC) is actively involved in public and professional accreditation. This institute has almost a century of history and was created on June 2, 1920 as the Canadian Society of Technical Farmers. The idea of an organization dedicated to the professional aspects of agriculture in Canada was borrowed by others, and its branches were rapidly formed throughout the country. By 1944, the Canadian Society of Technical Agronomists became Agricultural Institute of Canada.

Over time, nine branches in various provinces of Canada took over the functions of education management, recognizing and supervising professional groups. In 1995, after nearly a decade of discussion and debate, the members of Agriculture Institute of Canada voted to restructure the organization into a federation, which included the representatives of agricultural organizations and affiliates from many provinces of Canada [9].

Throughout its history to the present moment, Agricultural Institute of Canada strives to meet the needs of its members in rural community service, playing a central role as a source of reliable information for the Canadian agriculture and food sector. The Institute established itself as one of Canada's leading representatives in agricultural research and is an important tool for the promotion of agricultural research for scientists and stakeholders in the agricultural industry.
The Professional and Public Accreditation Program was initiated in 1998 at the request of the Confederation of Canadian Faculties of Agriculture and Veterinary Medicine. At that time, AIC, in partnership with the Agency for Quality in Education were accrediting bachelor's degrees to Canadian universities in 8 agricultural departments to ensure that graduates from these departments meet professional requirements and competencies.

AIC also supported programs to assist those who were assessing candidates for certification in agricultural skills. AIC expanded its professional services by assessing essential equivalence of agricultural production, food science and agricultural business programs offered by foreign universities with Canadian ones [10]. of:

The accreditation program includes the assessment

- the fundamental knowledge in relevant natural and social sciences;

- the general knowledge of the agri-food cycle system;

- the sufficient depth of knowledge and practical skills in their area of specialization;

- the ability to think critically and solve problems, especially in a team

- the ability to communicate orally and in written form;

- the computer literacy;

- the high appreciation of arts and humanities;

- understanding the elements of business agriculture

- the knowledge of the profession and ethical professional behavior.

After the appropriate comprehensive assessment and analysis, the program is accredited

Together, AIC and the Agency for the Quality of Education provided accreditation for more than 50 agricultural programs in 8 universities

Since 2007, the AIC Accreditation Program has expanded its mandate to include agricultural program evaluations at institutions outside Canada. These assessments follow the same policies and procedures and use the same criteria and high standards.

The experience of professional and public accreditation in the United States is also interesting, which concerns the training of engineering personnel, including in a number of agricultural engineering specialties.

In 1932, 7 engineering societies founded Engineering Council of Professional Development (ECPD):

- American Society of Civil Engineers (ASCE)

- American Institute of Mining and Metallurgy Engineers, currently American Institute of Mining, Metallurgical and Petroleum Engineers (AIME)

- American Society of Mechanical Engineers (ASME)

- American Institute of Electrical Engineers (AIEE)

- Society for the Advancement of Engineering Education, now the American Society for Engineering Education (ASEE)

- American Institute of Chemical Engineers (AIChE) 
- National Council of State Councils of Engineering Examiners (NCSCE)

The engineering professional organization devoted to education, accreditation, regulation and professional development of engineering professionals and students in the United States was established. From the day of its foundation until 1996, the main office of the organization was located in New York and then it moved to Baltimore, Maryland.

From the very beginning, such educational standards were developed that served as the basis for quality when professional engineers obtained permits for their work [11].

In 1936, the ECPD assessed their first engineering degree programs. Ten years later, the Council began assessing engineering technology education programs. By 1947, ECPD had accredited 580 undergraduate engineering programs at 133 educational institutions.

In 1980, ECPD was renamed as Accreditation Board for Engineering and Technology (ABET) to better describe the emphasis on accreditation.

In response to the anticipated boom in computer science and education, ABET helped to establish the Computing Science Accreditation Board (now called CSAB) in 1985. By the moment of its consolidation with ABET in the early 2000s, CSAB became one of the largest member societies, with over 300 accredited programs. Today this organization includes 35 member societies.

ABET's international activities began in 1979 when ECPD signed the first mutual recognition agreement with the Council of Engineers of Canada.

In 1997, after nearly ten years of development, the Engineering Criteria 2000 (EC2000) were developed and adopted, considered at that time as a revolutionary approach to accreditation criteria. EC2000 focuses on results (existing), not what is taught. In fact, EC2000 has reaffirmed the importance of institutions setting clear goals and assessment processes to ensure that each program provides graduates who are in demand for their technical and vocational skills.

ABET has been recognized by the US Council for Higher Education Accreditation (CHEA) since 1997. After more than 80 years of advancement these accreditation programs and procedures, the programs accredited by Engineering Accreditation Commission (EAC) remain the gold standard for engineering majors [11].

The analysis of various approaches shows the positive role played by professional and public accreditation of educational programs in agricultural sector. This tool also plays a positive role for the employment of graduates of agricultural universities, who know that they are getting education that is in demand at labor market [12].

\section{Conclusion}

Today, the world and Russian expert community is actively discussing methodological issues of the quality of education. Most often, the quality of education is characterized and described through a system of interrelated components, in determining the number of which there is also no consensus. UNESCO, for example, identifies five key components that determine the quality of education:

- learners who are "healthy, well nourished, ready for activity and learning";

- environment which is "healthy, safe, protected, taking into account gender characteristics, having the necessary resources";

- content, contributing to the acquisition of life skills and knowledge;

- processes where well-trained teachers use studentcentered teaching techniques and technologies;

- outcomes which are knowledge, skills and values associated with national priorities.

This model is fully expressed in the materials of the Ministry of Education and Science of Russia. The concept of "quality of education" is considered in two main aspects: from the point of view of the quality of the result, that is, the compliance of the level of knowledge of students and graduates with the requirements of standards, and from the point of view of the characteristics of the system for ensuring this quality, namely, the content of education, the level of training of teaching staff, information-methodological support of the educational process, the use of innovative educational technologies.

We share the position according to which the quality of education is considered as an integral characteristic reflecting the degree of compliance of the achieved results with regulatory requirements, social and personal expectations of students. In addition, it seems important to focus on the role of students in the organization, implementation and assessment of the quality of educational services provided.

Accreditation as a form of recognition of educational activities exists in almost all developed countries of the world, and in most of them it is the participation of independent structures in assessing the quality of education.

The concept of public accreditation in education first appeared in Russian legislation in 1992. Today, professional and public accreditation of educational programs as a concept and form has become one of the areas of independent assessment of the quality of education in the Russian Federation, and its legal foundations were defined in the Federal Law as of December 29, 2012 No. 273-FZ "On Education in the Russian Federation".

According to legislative norms, professional and public accreditation of educational programs is a recognition of the quality and level of training of graduates who have mastered such an educational program in a specific educational institution carrying out educational activities that meet the requirements of professional standards for specialists, workers and employees of the corresponding profile.

Professional and public accreditation of professional educational programs is a recognition of the quality and level of training of graduates that meet the requirements of professional standards, the requirements of the labor 
market for specialists, workers and employees in various sectors of the economy.

Information about the professional and public accreditation of the educational program must be taken into account when conducting state accreditation of educational organizations. An independent assessment of the quality of education allows employers to obtain the quality and level of training of graduates of educational institutions that meet modern labor market requirements.

In accordance with the legislation of many countries of the Eurasian continent, including the Russian Federation, the results of professional and public accreditation are considered during the procedure of state accreditation of educational organizations, and can also be taken into account when forming the admission quotas for applicants.

The results of professional and public accreditation are:

- Formation of an effective instrument of responsibility and demonstration of the level of education quality to the state, society, applicants, students, alumni, business, the educational community and employees of the educational institution.

- Increasing the level of stakeholder confidence in the quality of educational services, the effectiveness and efficiency of the educational organization.

- Strengthening the image and brand of the educational organization in the educational services market.

- Increasing the competitiveness of graduates of an educational organization in the labor market.

- Involving employees of the educational organization in the development of the quality of educational services, increasing the degree of employee commitment to the idea of quality.

- Using the results of professional and public accreditation in the procedures of national state accreditation.

The participation of the professional community in the assessment of the quality of the educational process in Russian education system is now also becoming more and more noticeable, although real practice shows that this participation is rather limited and in most cases is formal.

The foreign experience of the USA and Canada shows that the development and implementation of a system of professional and public accreditation establishes clearly determined regulations, purposes and processes for the assessment of the quality of educational programs in this procedure by employers. This, in turn, helps graduates to find work quickly.

The interaction with the professional community is necessary at all the stages of design and implementation of basic educational programs, as well as in the process of expert assessment of educational results.

In this paper we used the materials that were received during the grant project 46 543902-TEMPUS-1-2013-1-SKTEMPUS-SMGR 'Development of public accreditation of agrarian (agricultural) education in Russia' SMGR RU (11) [12].

\section{References}

1. F. Nezhmetdinova et al., The problem of choice labor activity for university graduates in Russian Federation, Int. J. of Mechanical Engineering and Technology, 9(3), 661-769 (March 2018)

2. F.F. Dudyrev, O.A. Romanova, A.I. Shabalin, Vocational education system: how to learn to hear labor market signals? (National Research University Higher School of Economics, Institute of Education, Moscow, 2018) 40 p. Available at: http://spspo.ru/data/3398.pdf

3. A. Chuchalin, P. Shamritskaya, Engineering programs accreditation in Russia: An academic view, in: IEEE Global Engineering Education Conf. (EDUCON) pp. 171-174 (Abu Dhabi, 2016) doi: 10.1109/EDUCON.2016.7474549.

4. A.I. Chuchalin, P.S. Shamritskaya, Developing the unified accreditation system for engineering and technology programmes in Russia, in: Proc. of the 43rd SEFI Annual Conf. 2014 "Diversity in engineering education: an opportunity to face the new trends in engineering, pp. 196 (2015)

5. J.E. Froyd, P.C. Wankat, K.A. Smith, Five major shifts in 100 years of engineering education, Proc. of the IEEE, 100, 1344-1360 (May 2012)

6. G. Augusti, Subject-specific quality assurance and accreditation of engineering education in Europe, in: Proc. Int. conf. on engineering \& business education, innovation and entrepreneurship (Sibiu, Romania, October 18-21, 2012) pp. 387-392 (Lucian Blaga Univ. of Sibiu, Sibiu, 2012)

7. F. Alam, R. Sarkar, R. La Brooy, H. Chowdhury, Engineering education in $21^{\text {st }}$ century, AIP Conf. Proc., 1754, 020002 (2016) Available at: https://doi.org/10.1063/1.4958344

8. EUR-ACE Framework Standards for the accreditation of engineering programmes: approv. by the ENAEE Administrative Council on 14 March 2017, available at: https://www.enaee.eu/wpcontent/uploads/2018/11/EUR-ACEAUTHORISATION-PROCESS-rev-2020.pdf

9. Universities of Canada. Quality control. Available at: http://www.univcan.ca/universities/qualityassurance/professional-programs-accreditation/

10. Agricultural Institute of Canada. Available at: http://www.aic.ca/about-aic/

11. Accreditation Council for Engineering and Technology (ABET). Available at: HTTP://WWW.ABET.ORG/ACCREDITATION/

12. F.T. Nezhmetdinova et al., Professionally-public accreditation of the educational programs of agricultural profile: experience and prospects (Publishing house of Kazan SAU, 2017) 160 p. 